\title{
The Effectiveness of Collaborative Strategic Reading (CSR) and Cooperative-Discussion-Question (Coop-Dis-Q) in Teaching Reading Comprehension
}

\author{
Lulu Walidaini $^{\bowtie}$, Januarius Mujiyanto, Warsono Warsono \\ Universitas Negeri Semarang, Indonesia
}

\begin{abstract}
Article Info
Article History:

Recived 29 December

2020

Accepted 20 February

2021

Published 15

September 2021

Keywords:

Collaborative Strategic

Reading (CSR),

Cooperative-

Discussion-Question

(Coop- Dis-Q),

Reading

Comprehension,

Impulsive, and

reflective Cognitive

Learning. Style

Abstract

This study aims to measure the effectiveness of collaborative strategic reading (CSR) and cooperative-discussion-question (Coop-Dis-Q) strategies in teaching reading comprehension students with impulsive and reflective cognitive learning styles. To improve students' reading comprehension skills, the researcher wants to study both strategies. This research used $2 \times 2$ factorial experimental designs. The subjects were XI MIPA 1 and XI MIPA 4 classes of SMAN 1 Pangkah, Tegal Regency. They were divided into two groups, and categorized impulsive and reflective students. The instruments used were test, pre-test, post-test, and questionnaires. This research indicated that collaborative strategic reading (CSR) was more effective than cooperative-discussion-question (Coop-Dis-Q) to students with impulsive cognitive learning styles. Simultaneously, there was no significant difference between the students who were taught by using collaborative strategic reading (CSR) and those taught by cooperativediscussion-question (Coop-Dis-Q) with reflective cognitive learning style. It meant that CSR was more effective for the students with impulsive cognitive learning styles, while Coop-Dis-Q was effective for the students with reflective cognitive learning styles. Based on the findings, the researchers concludes that CSR and Coop-Dis-Q appeared to improve the students' reading comprehension skills for both impulsive and reflective students.
\end{abstract}




\section{INTRODUCTION}

English as an international language is one of the school subjects taught in Indonesia. It is taught as a foreign language. The students learn it actively and passively. The four English skills are introduced to the students with the aim that the students can master all of them. Those four skills are listening, speaking, reading, and writing.

Among those four skills, reading is the most important one. It has many benefits for students in real life. For example, it can give more information and knowledge, improve the readers' vocabularies, concentration and focus, memory, and influence the readers' writing style, as well as be an enjoyable activity leisure time. Harmer (2007) also gives a similar argument that reading can provide some purposes for the readers. It can be useful for academic purposes, the readers' career, and also for pleasure activity.

However, in Indonesia, the phenomena of reading happened tragically. Many readers read the text by reading only without comprehending. Based on many urgencies above, reading comprehension must be mastered by the readers, especially the students in this case. The students must be accustomed to comprehend all the text they read. To make students accustomed to reading comprehension activities, they must be trained and stimulated. The teacher should guide their students to be able to do reading comprehension. In building up students' skills in comprehending their reading, a teacher should know the appropriate technique and strategies in teaching them. Using the proper technique or strategy in developing students' ability, teaching reading comprehension will be easier. Fortunately, there are many strategies to achieve this goal. Many reading experts proposed some strategies like SQ3R, reciprocal teaching, collaborative strategic reading, cooperative-discussionquestion, cooperative, integrated reading, composition, and so forth.

Considering the factor that showed students today are more effective in learning and doing activity in teamwork than an individual one, collaborative strategic reading (CSR) is chosen to be the main topic of this thesis. CSR is assumed to match with the Indonesian 2013 Curriculum (K13) and teaching and learning style today. According to Klingner and Vaughn (1998), CSR is a teaching technique of reading comprehension, which treats the students collaboratively. In the process of CSR, there are four phases. The first is "preview." In this phase, students do a preview before reading the text entirely. Students do brainstorming and predicting the content of the text. Next is "click and clunk." It happens during the reading activity. Click here refers to the part of the text that makes sense to students. Then clunk refers to the part or idea in the text that does not make sense. The third is "get the gist." Students are demanded to memorize the most important place, person, or thing in this phase. It happens during a reading activity like click and clunk. And the last phase is "wrap up." Students do it after the reading process. They will generate some questions to check the understanding of the text. The question will use $5 \mathrm{~W} 1 \mathrm{H}$.

CSR has an aim to enhance reading comprehension and strengthen the conceptual learning that involves students being active. In the process of CSR, first, a teacher will initially demonstrate the phases (preview, click, and clunk, get the gist, and wrap up). After making sure all the students understanding each step, the teacher divided the student into heterogeneous groups. There are 4 to 5 students in a group. The group must collaborate and implement the CSR phase, and the teacher guides them as the facilitator. Moreover, all students will have their role in a group to apply CSR, and they will collaborate to develop their reading comprehension ability.

Meanwhile, another strategy that can be categorized as the new strategy chosen in this study is Cooperative Discussion and Question (Coop-Disc-Q). Coop-Disc-Q is developed by Gauthier (2001) of the University of Houston. This strategy is called Cooperative Discussion and Questioning (Coop-Dis-Q). Bender and 
Larkin $(2009$, p.178) state that "this strategy has three elements, cooperative-discussionquestioning that work together into Coop-DisQ strategy." Each element of coop-dis-q will improve and strengthen each other component of teaching reading comprehension. Gauthier (2001) suggests that the steps in Coop-Dis-Q are making group, the teacher sets the questions, discusses the text, question, and answer, and presents their result of the discussion.

Both strategies mentioned before have the similarity in the purposes and teaching reading comprehension through group discussion activity. In adult students, especially senior high school students, learning in a group will make their group members develop their ability. Sagirli and Ates (2016) also stated that group discussion activities in collaborative reading could make students learn better since they interact with other students having the same comprehension level. However, both strategies above also have a difference in their procedure.

Moreover, this study compared the effectiveness of the two strategies above to students with different cognitive styles when learning reading comprehension in the classroom. The two strategies are Collaborative Strategic Reading (CSR) and CooperativeDiscussion-Question (Coop-Disc-Q). Meanwhile, those cognitive styles that we intended are reflective and impulsive. Reflective and impulsive were chosen considering that every student has different learning styles in learning English. Therefore, reflective and impulsive were not chosen as the independent or dependent variable but as a moderator variable in this study.

Based on many considerations above, the CSR and Coop-Disc-Qstrategies were selected. Those two strategies are reputed as the appropriate solution for developing and improving students' reading comprehension, especially at the senior high school level. Collaborative activities are associated with $\mathrm{K} 13$, which can be applied to the Indonesian education context.

\section{METHODS}

Research design is guidance to do the research sequence. Related to the study's main purpose, the researchers used the quantitative method because this research needs a statistical analysis for analyzing the data. According to Mc Kay (2006), the quantitative research method is a research study used to analyze population and sample. While Gay (2011), quantitative research collects any analysis of numerical data to describe, explain, predict or control phenomena of interest.

The experimental design was adopted in this study. The purpose of an experimental study is to investigate the correlation between cause and effect and how far its correlation was conducted by giving certain treatment to experimental group one and experimental group two as the comparison.

This research used a $2 \mathrm{X} 2$ factorial design because it employed more than one independent variable, namely Collaborative Strategic Reading (CSR) and CooperativeDiscussion and Question (Coop-Disc-Q) strategies one dependent variable reading comprehension. The moderator variables employed to classify the participants were that is classified into reflective and impulsive cognitive styles. According to Gay (2011), factorial design refers to a design with more than one variable (or grouping variable), also known as a factor.

\section{RESULTS AND DISCUSSIONS}

\section{Teaching Reading Comprehension Using CSR to Students with Impulsive Cognitive Learning Styles}

Answering the first research question, we did a pre-test, giving the treatment used CSR technique and did the post test in students with impulsive cognitive learning style. After all of them was done, the result can be described Table 1. 
Table 1. Paired Sample Statistic of Class One with Impulsive Cognitive Learning Style

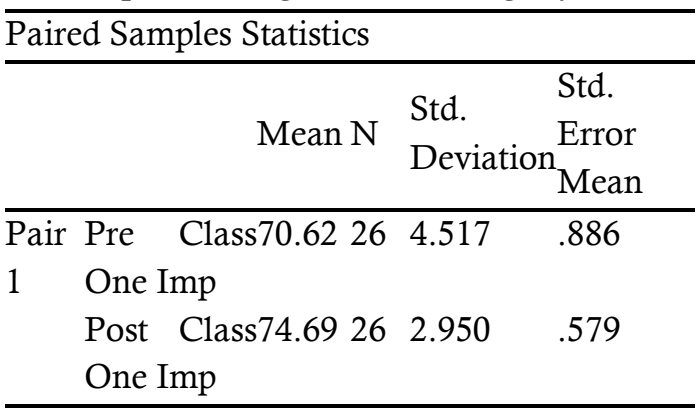

Table 1 shows that there was a significant difference between the students' reading skills in pre-test and post-test. The mean score of the pre-test (70.62) was lower than the post-test mean score (74.69). It means that the students with impulsive personalities had a high score and showed improvement. The t-value also supported it. T-value was higher than the t-table. It showed that $0.001<$ 0.05 . Therefore, Ho was rejected. It means that using the CSR technique effectively enhanced the reading comprehension skills of the students to impulsive personality. This finding is supported by Putri et al. (2015) and Agustina (2017) who mentioned that CSR is one of the good techniques in enhancing the students' reading comprehension. The steps of CSR technique which are preview, click and clunk, get the gist and wrap up are assumed match with the characters of the impulsive students who almost do everything spontaneusly. Putri et al. (2015) suggested that collaborative strategic reading could be utilized in teaching reading due to its exciting process. The students could enjoy the teaching and learning process and allow the students to develop their reading comprehension. Agustina (2017) proved that collaborative strategic reading could be implemented for teaching students with any attitude toward the teaching and learning process in improving their reading comprehension

\section{Teaching Reading Comprehension Using CSR to Students with Reflective Cognitive Learning Styles}

Answering the second research question, we did pre-test, gave the treatment used CSR technique and did the post test in students with reflective cognitive learning style. After all of them was done, the result can be described Table 2.

Table 2. Paired Sample T-test of Class One with Reflective Cognitive Learning Style

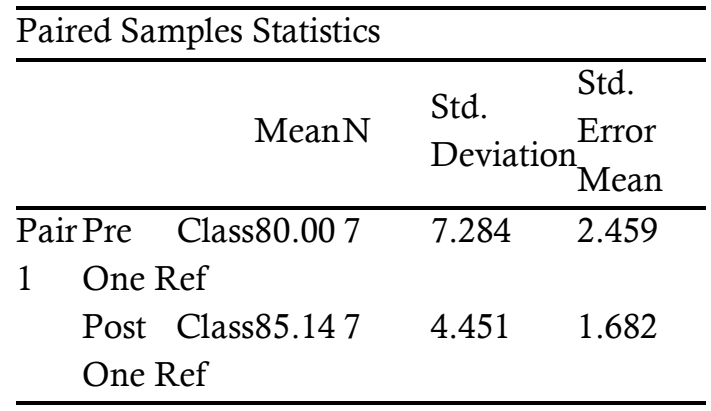

Table 2 shows that there was a significant difference between the students' reading skills in pre-test and post-test. The mean score of the pre-test (80.00) was lower than the post-test mean score (85.14). It means that students with reflective personalities had a high score and showed improvement. The tvalue also supported it. T-value was higher than the t-table. It showed that $0.022<0.05$. Therefore, Ho was rejected. It means that using the CSR technique effectively enhanced the reading comprehension skills of students to reflect personality. This finding in a line with Karabuga (2013) and Indah (2019) which mentioned that CSR technique was effective in teaching students reading comprehension. $\mathrm{He}$ found that CSR has the power on its collaboration technique which can engage some students to have a good teamwork in enhancing their reading comprehension. It is good for the reflective students who did everything perfectly to help the other students. Indah and Yahmun (2019) found out that collaborative strategic reading is an exciting reading activity for the students, contributing to their reading comprehension score. 


\section{Teaching Reading Comprehension Using Coop-Disc-Qto Students with Impulsive Cognitive Learning Styles}

Answering the third research question, we did a pre-test, gave the treatment using Coop-Dis-Q technique and did the post test to the students with impulsive cognitive learning style. After all of them was done, the result is described in Table 3.

Table 3. Paired Sample Statistic of Class Two with Impulsive Cognitive Learning Style

\begin{tabular}{|c|c|c|c|}
\hline \multicolumn{4}{|c|}{ Paired Samples Statistics } \\
\hline & Mean N & $\begin{array}{l}\text { Std. } \\
\text { Deviation }\end{array}$ & $\begin{array}{l}\text { Std. } \\
\text { Error } \\
\text { Mean }\end{array}$ \\
\hline Pair Pre & Class69.04 27 & 4.784 & .921 \\
\hline Two & $\mathrm{mp}$ & & \\
\hline $\begin{array}{l}\text { Post } \\
\text { Two }\end{array}$ & $\begin{array}{l}\text { Class71.85 } 27 \\
\mathrm{mp}\end{array}$ & 4.073 & .784 \\
\hline
\end{tabular}

Table 3 shows that there was a significant difference between the students' reading skills in pre-test and post-test. The mean score of the pre-test (69.04) was lower than the mean score of the post-test (71.85). It means that the students with impulsive personalities have a high score and showed improvement. The t-value also supported it. Tvalue was higher than the t-table. It showed that $0.023<0.05$. Therefore, Ho was rejected. It means that using the Coop-Dis-Q technique effectively enhanced the reading comprehension skills of the students with impulsive personality. This finding supports Spencer (2018) who identified that the implementation of coop-dis-q has significantly improved the students' reading comprehension, allowing them to learn together effectively in comprehending a text. The interactions among the students inside make a good environment to work cooperatively.
Teaching Reading Comprehension Using Coop-Disc-Q to Students with Reflective Cognitive Learning Styles

Answering the third research question, we did a pre-test, gave the treatment using the Coop-Dis-Q technique and did the post test to the students with reflective cognitive learning style. After all of them was done, the result can be described in Table 4.

Table 4. Paired Sample Statistic of Experiment Class Two with Reflective Cognitive Learning Style

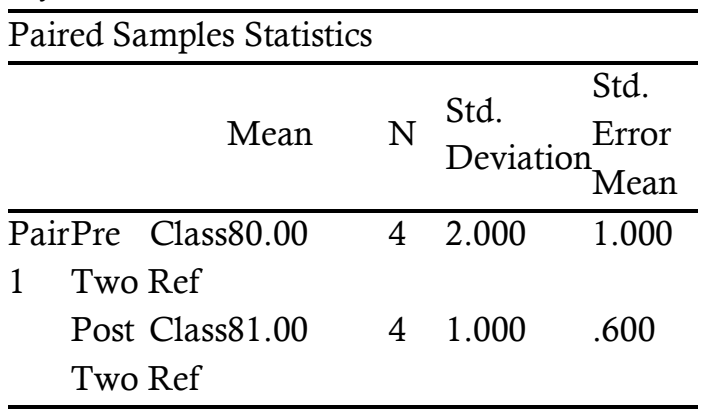

Table 4 shows that there was a significant difference between the students' reading skills in the pre-test and post-test. The mean score of the pre-test (80.00) was lower than the post-test mean score (81.00). It means that students with reflective personalities had a high score and showed improvement. The tvalue also supported it. T-value was higher than the t-table. It showed that $0.039<0.05$. Therefore, Ho was rejected. It means that using the Coop-Dis-Q technique effectively enhanced students' reading comprehension skills to reflective learning styles. This finding is supported by Anggara et al. (2018) proved that coop-dis-q had been an effective strategy in improving the students' reading comprehension score. The discussion session and questioning time make the reflective students prepare more during the teaching and learning process.

Teaching Reading Comprehension Using CSR and Coop-Disc-Q to Students with Impulsive Cognitive Learning Styles

CSR and Coop-Dis-Q are the techniques found to enhance the students reading comprehension skill. Both of them have their 
ways to enhance the students' reading comprehension skill. We chose analyzing those skills to compare which one of them was better in enhancing reading comprehension skill of the students with impulsive cognitive learning style. After applying those skills to the students in two experimental classes. The result is presented in Table 5.

Tabe1 5. Group Statistics of Class One and Two with Impulsive Students Cognitive Style

\begin{tabular}{|c|c|c|c|}
\hline \multicolumn{4}{|c|}{ Descriptive Statistics } \\
\hline & $\mathrm{N}_{\mathrm{n}}^{\mathrm{Mi} \mathrm{Ma}}$ & $\begin{array}{l}\text { Mea } \\
\mathrm{n}\end{array}$ & $\begin{array}{l}\text { Std. } \\
\text { Deviatio } \\
\text { n }\end{array}$ \\
\hline \multicolumn{4}{|c|}{ 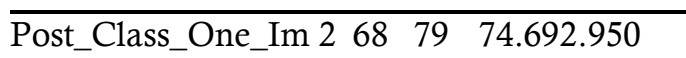 } \\
\hline \multicolumn{4}{|c|}{$\mathrm{p}-6$} \\
\hline \multicolumn{2}{|c|}{ Post_Class_Two_Im 26476} & \multicolumn{2}{|c|}{71.854 .073} \\
\hline $\mathrm{p}$ & 7 & & \\
\hline \multirow[t]{2}{*}{ Valid N (listwise) } & 2 & & \\
\hline & & & \\
\hline
\end{tabular}

Table 5 shows a significant improvement by using CSR and Coop-Disc-Q to the students with impulsive cognitive learning style. The mean score of CSR (74.69) was higher than the mean score of Coop-Disc-Q (71.85) for the students with impulsive cognitive learning style. The t-value also supported this result. Where the t-value (0.048) was less than 0.05. Therefore, Ho was rejected, and $\mathrm{Ha}$ was accepted. The CSR technique was more effective than the Coop-Disc-Q technique to teach reading comprehension skill to students with impulsive personality. This finding is in line with Zagoto (2016), CSR made students' have better in reading comprehension skill. It is because of its' strategy is so helpful for the students understanding what they read. Furthermore, the students with impulsive cognitive learning styles and their spontaneous character were appropriate to be taught using this technique.
Teaching Reading Comprehension Using CSR and Coop-Disc-Q to Students with Reflective Cognitive Learning Styles

CSR and Coop-Dis- $Q$ are the techniques found to enhance the students reading comprehension skill. Both of them have their ways to enhance the students' reading comprehension skill. We chose analyzing those skills to compare which one of them was better in enhancing reading comprehension skill to the students with reflective cognitive learning style. After applying those skills to the students in two experimental classes, here the result is shown in Table 6.

Tabel 6. Group Statistics of Class One and Two with Reflective Students Cognitive Style

\begin{tabular}{llllll}
\hline \multicolumn{1}{l}{ Descriptive Statistics } & & & \\
\hline & $N$ & Min & Max Mean & $\begin{array}{l}\text { Std. } \\
\text { Deviation }\end{array}$ \\
\hline Post Class10 & 80 & 92 & 84.00 & 4.216 \\
One Ref & & & & \\
Post Class8 & 80 & 84 & 80.50 & 1.414 \\
Two Ref & & & & \\
Valid & N8 & & & & \\
(listwise) & & & & & \\
\hline
\end{tabular}

Table 6 shows a significant improvement by using CSR and Coop-Disc-Q to the students with reflective personality. The mean score of CSR (84.00) was higher than the mean score of Coop-Disc-Q (80.05) to students with reflective personality. The t-value also supported this result. Where the t-value 0.048 was less than 0.05. Therefore, Ho was rejected, and $\mathrm{Ha}$ was accepted. The CSR technique was more effective than the Coop-Disc-Q technique to teach reading to the students with reflective personality. Teaching reading comprehension with CSR, Putri et al. (2015) suggested that collaborative strategic reading could be utilized in teaching reading due to its exciting process. The students could enjoy the teaching and learning process and it allowed the students to develop their reading comprehension. 


\section{The Interaction Effect among Techniques CSR and Coop-Disc-Q, Reading Comprehension Skill and Students' Cognitive Learning Styles}

In order to measure the interaction among the technique, students' cognitive learning style, and reading comprehension skill of the eleventh-grade of SMAN 1 Pangkah, ANOVA was used to analyze the data. In this way, the interaction between techniques, students' learning cognitive style, and reading comprehension skill is displayed Table 7.

Table 7. Test of Between-Subject Effect the Test of Interaction of ANOVA

\begin{tabular}{|c|c|c|c|c|}
\hline \multicolumn{5}{|c|}{ Tests of Between-Subjects Effects } \\
\hline \multicolumn{5}{|c|}{ Dependent Variable:Reading Comprehension } \\
\hline \multirow[t]{3}{*}{ Source } & \multicolumn{4}{|l|}{ Type III } \\
\hline & \multirow{2}{*}{$\begin{array}{l}\text { Sum of } \\
\text { Squares df }\end{array}$} & \multicolumn{3}{|l|}{ Mean } \\
\hline & & Square & $\mathrm{F}$ & Sig. \\
\hline Corrected & $19.893^{\mathrm{a}} 2$ & 9.946 & .329 & .722 \\
\hline \multicolumn{5}{|l|}{ Model } \\
\hline Intercept & 59.6701 & \multicolumn{3}{|c|}{59.670417 .189 .000} \\
\hline Pre_Test & .686 & .686 & .023 & .881 \\
\hline Post_Test & 4.074 & 4.074 & .135 & .716 \\
\hline Pre_Test & *.307 & .307 & .762 & .516 \\
\hline \multicolumn{5}{|c|}{ Post_Test } \\
\hline Error & 1.3303 & \multicolumn{3}{|l|}{.252} \\
\hline Total & \multicolumn{4}{|l|}{132.00036} \\
\hline Corrected & \multicolumn{4}{|l|}{158.22235} \\
\hline \multicolumn{5}{|l|}{ Total } \\
\hline \multicolumn{5}{|c|}{$\begin{array}{l}\text { a. } \mathrm{R} \text { Squared }=.020 \text { (Adjusted R Squared }=\text { - } \\
.040 \text { ) }\end{array}$} \\
\hline
\end{tabular}

This part discusses the interaction among the techniques, reading comprehension, and students' cognitive styles. From the calculation, the significant value $(0.516)$ was higher than 0.05 . It means that there was no interaction among CSR and Coop-Disc-Q techniques, students' cognitive style, and reading comprehension skill. The finding of this research indicates that the CSR technique was more effective in teaching the students with the impulsive personality and Coop_Disc_Q technique effectively teaches the students with reflective personality. This is in line with Rosari and Mujiyanto (2016) who proved that the strategy know-want-learned and collaborative strategic reading could help the students in reading comprehension for both students with positive and negative attitudes

\section{CONCLUSIONS}

The conclusions of this current research can be drawn from the findings above that collaborative reading strategies (CSR) correlate significantly to students' reading comprehension. The application of collaborative reading strategies is a must because it has contributed to the students' reading comprehension. Collaboration reading strategies are important factors in determining students' reading comprehension. Based on the findings, this article suggests some items: 1) Reading strategies should be taught in the classroom intensively to improve EFL reading skill and their reading comprehension; 2) For policymakers, it is important to consider cognitive reading strategies, especially for developing reading curriculum for higher-level education students, because reading is a critical skill in getting information and knowledge.

This research emphasis is on the comparison of the effectiveness of two techniques of teaching and learning reading comprehension skill. They are the use of comprehension strategic reading (CSR) and cooperative discussion and questioning (CoopDisc-Q) technique. The objectives of the research were to answer the seven formulated research questions. In the previous chapter, the data derived from experiment class one and experiment class two were analyzed. The results of the research are as follows:

The first result indicated that there was a significant difference in the mean score between pre-test and post-test with impulsive students personality taught by using CSR technique. The result revealed that CSR technique was effective to use in teaching reading comprehension to the students with impulsive personality.

The second result indicated that there was a significant difference in the mean score 
between pre-test and post-test of experiment class one with reflective personality. It meant that CSR technique was effective to use in teaching reading comprehension to the students with reflective personality in experiment class one.

The third result showed that there was a significant difference in the mean score between pre-test and post-test of experiment class two of the students with impulsive personality. It meant that Coop-Disc-Q technique was effective to use in teaching reading comprehension to the students with impulsive personality.

The fourth result explained that there was a significant difference in the mean score between the pre-test and post-test of the experiment class of the students with reflective personality. It meant that Coop-Disc-Q technique was effective to use in teaching reading comprehension to the students with reflective personality.

Answering the fifth research question, there was a significant difference in the effectiveness of the CSR technique and CoopDisc-Q technique to teach reading comprehension to students with impulsive personalities. It can be seen that the mean score of students in experiment class one with impulsive personality was higher than that of students in experiment class two with the same personality type. It means that the CSR technique is more effective than Coop-DiscQtechnique to use in teaching reading comprehension to students with impulsive personalities.

The sixth result explained that there was no significant difference in the effectiveness of CSR technique and Coop-Disc-Qtechnique to teach reading comprehension to the students with reflective personality. It can be seen that the significant value $(0.482)$ in table 4.22 is more than 0.05 which means there is no significant difference. Moreover, there is no significant difference between the students taught by using the CSR technique and those taught by using Coop-Disc-Q with reflective students' personalities.
While the last result explained that there was no interaction among the techniques, students' personality, and reading comprehension skills. It means that the CSR technique is more effective for students with impulsive and reflective personalities.

\section{REFERENCES}

Agustina, E. (2017). The influence of collaborative strategic reading (CSR) and reading attitude toward reading comprehension achievement to the tenth-grade students of SMA Negeri 1 Buay Madang Oku Timur. Journal of English Language Education and Literature.

Alqarni, F. (2015). Collaborative strategic reading to enhance learners' reading comprehension in English as a foreign language. Academic Journal of Interdisciplinary Studies, 4(1).

Anggara, I., Saleh, M., \& Sofwan, A. (2018). The Effectiveness of Coop-Dis-Q and Literature Circle Strategies in Teaching Reading Comprehension to Students with Different Personalities. English Education Journal, 8(1), 66-75.

Cahyono, B. \& Widiati U. (2006). The teaching of EFL reading in the Indonesian context: the state of the art. TEFLIN Journal, 17(1).

Dewi, N. M., Warsono. \& Faridi, A. (2018). Integrating collaborative strategic reading with learning logs: an alternative method to develop reading comprehension. English Education Journal, 8(2).

Gauthier, L.R. (2001). Coop-Dis-Q a reading comprehension strategy. Intervention in School and Clinic. 36, 217-220. Retrieved on 19th November 2011.

Indah, C. H. R., \& Yahmun. (2019). Implementing collaborative strategy to improve reading comprehension the eleventh graders of SMK Kertha Wisata Malang. E-Journal Budi Utomo Malang. 
Karabuga, F., \& Kaya, E. S. (2013). Collaborative strategic reading practice with adult EFL learners: A collaborative and reflective approach to reading. Procedia - Social and Behavioral Sciences, 106, 621-630.

Klingner, J. K., \& Vaughn, S. (1999). Teaching reading comprehension through collaborative strategic reading. Intervention in School and Clinic, 34(5), 284-292.

Klingner, J. K., Vaughn, S., Arguelles, M. E., Tejero Hughes, M., \& Ahwee Leftwich, S. (2004). Collaborative strategic reading. Remedial and Special Education, 25(5), 291-302.

Mistar, J., Zuhairi, A., \& Yanti, N. (2016). Strategies training in the teaching of reading comprehension for EFL learners in Indonesia. English Language Teaching, 9(2),

Putri, A. K., Ohiwutun, J. E., \& Wahyudin (2015). Using collaborative strategic reading (CSR) to develop reading comprehension of the secondyearstudents. e-Journal of English Language Teaching Society, 3(2).

Rosari, L., \& Mujiyanto, Y. (2016). The effectiveness of know-want-learned and collaborative strategic reading strategies to teach reading comprehension to students with positive and negative attitudes. English Education Journal, 6(2).

Septiani, R. et al. (YEAR). The effectiveness of collaborative strategic reading (CSR) towards the reading comprehension of the first grade students of SMAN 14 Pekanbaru. Jurnal Online Mahasiswa Fakultas Keguruan dan Ilmu Pendidikan Universitas Riau, v4(1), 1-8.

Shaban, S., Ramazani, M., \& Alipoor, I. (2017). The effect of impulsivity vs. reflectivity on reading comprehension of Iranian EFL learners. International Journal of Education and Literacy Studies, 5(3), 52.

Zagoto, I. (2016). Collaborative strategic reading (CSR) for better reading comprehension. Komposisi: Jurnal Pendidikan Bahasa, Sastra, dan Seni, 17(1), 65.

Marzona, Y., \& Astria, W. (2019) The effect of questioning strategy and students' motivation toward reading comprehension of narative text at the eleventh grade Social Science of SMA Negeri 1 Talamau Pasaman Barat. Jurnal Ilmiah Pendidikan Scholastic, 3(2), 32-39. 